\title{
Recoil Delicately Checked and Utilised
}

\section{Lieutenant-General W. N. Hutchinson \& Captain Robert Scott R.N.}

To cite this article: Lieutenant-General W. N. Hutchinson \& Captain Robert Scott R.N. (1869) Recoil Delicately Checked and Utilised, Royal United Services Institution. Journal, 13:53, 75-83, DOI: $10.1080 / 03071846909417023$

To link to this article: http://dx.doi.org/10.1080/03071846909417023

\section{曲 Published online: 25 Sep 2009.}

Submit your article to this journal

Џلl Article views: 2

Q View related articles $₫$ 


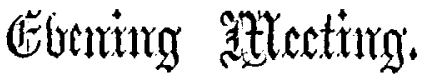

Monday, February 1st, 1869.

ADmirar Sm IIENRY J. CODRINGTON, K.C.B., in the Chair.

M.IMES OF MIEICBERS who joined the Institution betreen tho 18th January and the 1st February, 1869.

ANNUAL.

Aton, E. W. F., Capt. 1st Roy. Cheshire Innes, J. Mr. AreLeod, O.te., Major Roy. Milil. $1 l$.

$\$$. jer, J. R. S., Col. Asst. Commt., Car. Depôt, Canterbury. 11 .

$\therefore$ uddert, T. A. Fitzgerald, Capt. Lond. drt. Vols. 1 l.

ilson, Charles TV. II., Capt. 6th The Royal Regt.

rekburne, James G., Capt. 6th The Royal Rert.

arrison, Thomas P., Capt. 107th Regt. 11.

rdon, Robert TV. T., Licut., 93rd Highrs. $1 l$.

otter, IIcnry, Licut. Roy. Engrs. $1 l$.

Engrs., Bengal. 11 .

Thackeray, E. T., W.E., Capt. Roy. Eagrs. Bong. $1 l$.

Ready, John T., Capt. 66th Regt. $1 l$.

Stcphens, Edmund, Lt. Roy. Lingrs. 11.

IIenderson, W. Hallam, Lieut. Rojal Engrs. $1 l$.

O'brien, E. D. C., Licut. Rog. Engrs. 11.

Wallace, Charles J. S., Lieut-Col. 25th K. O. Dorderers.

Ruddell-Todd, James $\Lambda$., 3Iajor 25th I. O. Borderers.

Seriven, IIorace IV., Capt. 25th K. O. Borderers.

\section{RECOIL DELICATELY OHEGKED AND UTILISED.}

By Lieutenant-General W. N. Hurchrssox.

Rend by Captain Rodert Scotr, R.N.

Tne increasing power of resistance constantly added to defensivo armour gives a proportionately increasing importance to ordnanco throwing heary charges, and bespeaks a careful consideration of any proposed improvement in the principle of checking recoil, for it is well known that the rango and effieiency of powerful guns are much diminished from the inability to fire as large charges of powder from them as would be practicablo, wero it not for the evils arising from the great recoil occasioned by large charges. In August, 1863, the Urdnauco Select Committec reported "that wrought iron guns might 
"be made lighter than they are, or be used with heavier charges, if " the recoil could be more effectually checked." The present proposition for more efficiently checking recoil is by the use of the most elastic and inexpensive cushion known, viz., the common atmosphere, which can be employed in tho most delicate, jet effectivo manner, and to any amount.

The application is by the use of a closed cylinder, with a piston and rod working in it, having much air on one side of the piston, and very little on the other (see Plate v, figs. 1 and 2 ).

When recoil takes place, the piston is forced into the part containing the greater body of air, which is thereby compressed, while at the samo time the air on the other side of the piston is proportionably rarefied. The increasing resistance of the air thus gradually and quietly receives and absorbs the force of the blow from recoil. This smooth absorption of recoil allows of the employment of a gum much lighter than the ordinary gun, supposing the weight of powder and shot to bo tho measure of the similarity in both.

To utilise the rebound that would instantly occur from the elasticity of the highly-compressed air, a self-acting catch (or other contrivance) retains the gun (with carriage) in its back position until loaded; then, when the catch is released, the pressure of the compressed air against the piston most usefully assists in running out the gun to firing position.

With very light guns (which are particularly desirable on turntables) when very heavy charges are fired, the air will be moro compressed by recoil than is required to return the gun to firing position. This storedup-force can be smoothly eased off by means of a light hand-rope rove through double-sheaved pullies, or bo controlled by means of a friction band, \&c. But were all precautions neglected little inconvenience could arise; for the air that had been rarefied at one end of the cylinder, becoming in its turn gradually compressed as the gun resumes its firing position, would act as a soft cushion, and prevent mischief at the termination of the rebound.

Fig. 3. - When a gun is mounted on an ordinary carriage, the cylinder, constructed as shown in Fig. 3, is attached to the carriago below the gun, not far from the trunnions. The piston-rod lies nearly horizontal in a rertical plane with the axis of the bore, the exterior end of the rod being towards the muzzle. This end of the rod plays freely in a ring (or circular staple, or eye) fixed below the sole of the embrasure or port-hole. Thus the free training of the gun is not in the least impeded. When the gun recoils, it carries the cylinder with it, compressing the air in front of the almost stationary piston. All the forco of the recoil is thus absorbed without friction, and without causing the least jar or strain to any part of the carriage or platform, for it is obrious that all the horizontal strain is borne by the ring.

For the sake of security this ring might play in the angular part of two strong iron bars joined together in the form of a letter $V$, ruming for many feet horizontally through the parapet. To the extremity of these bars would be attached largo flat bars or beams, fixed crosswiso and vertically in tho body of tho parapet. 


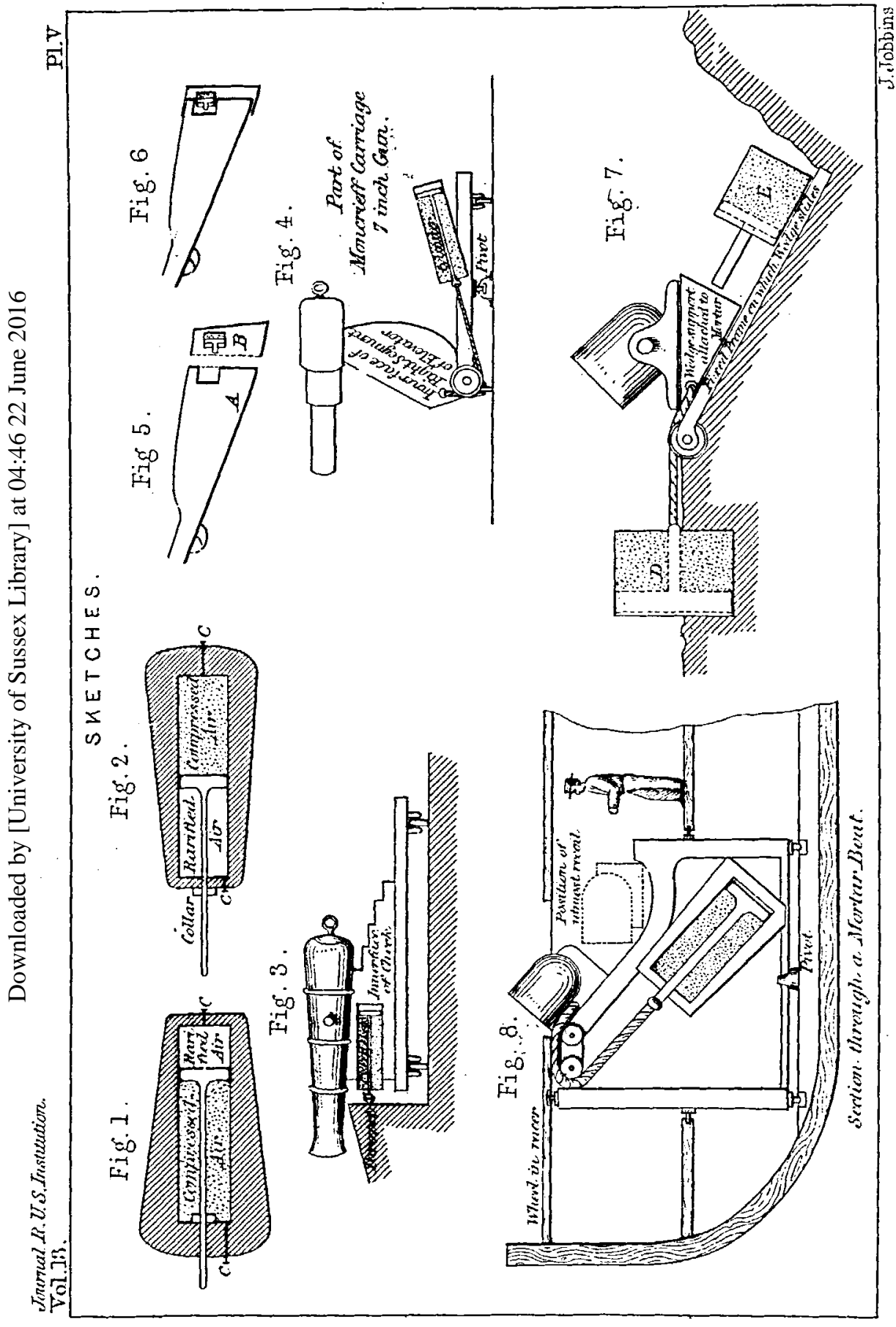


In applying tho cylinder, made according to Fig. 1, as a substitute for the weight in Moncrieff's carriages, it would be firmly attached to the after-part of the traversing platform.

A flexible ropo (passing over a pulley, fixed vertically, in the front and lower part of the platform), would be attached to the exterior end of the piston-rod, and would connect it with the centre of the horizontal cross-bar which unites the front extremities of the toothed segments constituting the sides of the carriage. The rope intervening between this cross-bar and the end of the piston-rod would bo about the length of the rod, which would bo the measure of the limit of recoil.

Recoil would cause the trunnion-ends of the segments to roil inwards with the gun, and sink below tho crest of the parapet,- the too sudden elevation of the other ends being, soon after starting, gradually more and more resisted by the gradually increasing density given to the air by the rope pulling forward the piston.

Tho cylinder, if sufficiently increased in diameter (therefore in power), need only be half the described length, were the rope, when fastened to the front of the traversing platform, to be passed through a pulley fixed at the exterior end of the piston-rod before it passed over the other pulley.*

By a little alteration of the disposition of the parts which connect the sides of most gun-carriages, ample spaco would be found for tho proper adjustment of the cylinder.

Marks on the rod would show at all times the exact position of the piston within the cylinder.

$C, C, C, C$, are air-cocks occasionally turned to allow the entrance or escape of air, and thus regulate to the greatest nicety the resistance to be given by the compressed air, and the length of the stroke of the piston. It is clear that the less the air is admitted into the vacuum-end of the cylinder the greater will be the resistance of the compressed air, and consequently the less will be the length of stroke, and the less the length of recoil. This principle of checking it, gives such absolute control over the gun, that all rapidity of recoil might be prevented $a b$ initio. By bringing the piston home to the head of the cylinder there would be practically a perfect vacuum at that end, when the gun's starting to recoil would be resisted by a pressure exceeding $14 \mathrm{lbs}$. per square inch of every inch of the piston's area, even should the cylinder be only charged with air of natural density.

Were there any advantage in the arrangement (which is doubtful), any greater resistance at starting could bo made uniform during the whole of the recoil by means of a safety-valve placed at the end of the cylinder, whose spring would more and more yicld to the escape of air as its pressure increased. It must bo obvious that wore the end quite open, the pressure might always be 14 lbs. to the square inch, both for resisting recoil and for running out the gun.

* When cramped for space, instead of the compressed-air end of the cylinder being closed in the usual menner by haring a globulous reserroir attached to the sides near the cnd, and the lowest part of the sides thus encascd piereed with holes communicating with tlic rescroir, the piston might be driren home the full length of the eylinder.-IV.N.II. 
It has been suggested that there rould be danger of leaknge of air wero the gun retained for hours in the loading position,-brt manufacturers will assure you that with careful workmanship, there need be no apprelsension on that score. The motion of the piston is slow. The pressure of the condensed air, unlike that in a steam-cylinder, is always on one and the same side of the piston, therefore the compressed air is constantly forcing the soft, well-greased paching into any crevice that might otherwise exist between the uppermost plate of the piston and the side of the cylinder. Moreorer, the collar round the pistonrod boing always in the air of greatest density (inside the cylinder, Fig. 1, outside the cylinder, Fig. 2), is always pressed against thio piston-rod, which prevents any escape in that part,-but were there even a slight escape, it could readily be replaced by the air-pump.

In the two foregoing instances of recoil being checked, it was resisted by the piston-rod being partly drawn out of the cylinder, but in the case of wall-pieces and all arms fired from the shoulder, the force of recoil could be met by the piston-rods being driven into the cylinders (seo Fig. 2).

The stocks of such pieces would be in two parts. To the shoulderplate a small cylinder made on the principle shown in Fig. 2, is fixed within the stock. The part $A$ slides within the part $B$, see Fig. 5 . The two parts are usually together, as shown in Fig. 6. Recoil drives $A$ (say an inch, or inch and half) close to tho shoulder-plate, tho force of the blow being received on the piston; then $A$ returns, by the forco of the rebound, to its usual position. Rifled wall-pieces with stecl pointed projectiles were much employed by the Americans in their last war, and from their range, precision, and penetration, are likely to be frequently used in future to resist approaches by sap, \&c., especially as the adoption of the cylinder would allow of pieces of increased power being mannfactured. Only sap gabions of unheard-of diameter could resist penetratiou from such pieces.

Tho decks of iron-clads being their most vulnerable point, many think that mortars will be much used in future. It is clear that any arrangement which would admit of their recoiling, rionld greatly augment their power by allowing larger charges of powder being employed than can now be used. It is beliered that no attempt has as yet been mado to attain this desirable end, but endearours have been made, by supporting the beds of mortars on rulcanized india-rubber, to lessen the injurious strain given to a ship on their being fired. These attempts failed, principally from the constant weight of the murtars destroying the elasticity of the india-rubber.

It is now proposed (see Fig. 7), where a traversing platform may not be required, that the carriage shall be somewhat in the form of a wedge, - that on the mortar being fired, it shall recoil or slide downwards (towards the fixed cylinder $E$, and from the fixed cylinder $D$ ) on a wooden platform lying at such an inclination that the carringo will not slip down, but remain in the highest position until the mortar is fired,- that, after recoil, the carriage, with mortar, shall be retained by a catch in tho lowest position (where tho gunners will be sheltered) until it be re-loaded,-and that on being released by freeing the catch, 
the forco of the compressed air shall aid tho gumors in making it re-ascend. Of course tho wheels of the carriago will always self-lock during tho descent. Fow easier plans could be adopted for effecting this lock than the falling weight on a cogged wheel, as employed in a ship's windlass.

Where it would be inconvenient to place cylinders of such a sizo that air in its natural state would givo sufficient resistance, the power of both the cylinders might be increased by their being charged by an air-pump (attached to the air-cock), with air of the requisite density, as indicated by a gauge.

As there would always be amplo space for D cylinder, it could bo made of whatever sizo and power* might be required.

It is hoped that Fig. 8 will give a suficient general idea of the arrangement proposed when it is necessary that the recoiling-mortar should stand on a revolving platform. In a mortar-boat, a circular holo (say 7 feet in diameter) is cut in the upper deck, also in the lower. The inclined beams that support the carriage and mortar rest on a revolving frame standing on wheels, which travel in a circular groovo attached to the bottom of the boat. A projection (terminating in a wheel) from the upper part of the revolving framo prevents its lifting or receding when the mortar is fired. That wheel plays in a circular groove fixed underneath the upper deck, near the edge of the lole cut in it. Against the edgo of the lower deck (through which the revolving frame passes to the bottom of the boat) is also a racer in which work horizontal wheels to further steady the frame in a sea or during firing. The skids (or rails) on which the carriago glides are curred upwards towards their lower termination, to assist in checking recoil.

In pits on shore, or wherever additional weight would not be disadrantageous, a counterbalancing weight to tho mortar might be substituted for the cylinder.

Some naval men think that the adoption of a few mortars in our iron-clads would much add to their efficiency. If the shells projected, were made to rotate rapidly in the plane of their progress, they would gain in precision and penetration. This, it is belicred, could bo effected on the principle shown in the wooden model of a 32-pounder disc-gun, now in this Institution, and which was fully described in a paper read here on the 4th of February, 1867.t

Tho shot on starting is tripped, as it were, by a fised stecl catch, which fits into a notch, or small h-le cut on the surface of the shot. This causes the shot actually to spin during its light, and when alighting on level ground to roll rapidly for a long time in tho direc-

\footnotetext{
4* Of any porrer. The undersigned took out a patent, dated 1st February, 1561, for "Improvement 3 in the construction of Cylinders of If dralic Mrachines, appli" cable also to the construction of ordnance and other articles, or ressels subject to "pressure from within." It explained how in a cylinder composed of many consecutive tubes, each tube could be mauc to do as much useful duty as the innermost, in resisting a bursting strain, by a calculated pressure giren to the mercury (or any fluid) that slightly separated the sereral tubes.-W.N.II.

+ Printed in No. 43 of the R. U. S. I. Journal, rol. si.
} 
tion of aim. On striking an object, the force of the blow received is tho resultant of the horizontal trajectory and of the velocity imparted to the surface of the shot by the spin. None of the force of the powder is expended in overcoming the resistance to the shot's progress in the barrel (therefore to its initial velocity) caused by rifling.

All these cylinders, which are so simple in their application, would be durable and not expensive, while the certainiy and uniformity of their action without the risk of wrong manipulation (for they aro really self-acting), promises to give them an advantage over every kind of check from friction, however ingeniously applied; and the fact of the recoil, instead of continuing a detriment, being made to aid tho efficiency of the gun by the condensed air serving to run it out after it is loaded, thereby rendering but few gunners nevessary, argues strongly in favour of substituting cylinders for compressors on board ship.

It is thought that the employment of them to check the recoil of heavy guns, besides adding to their efficiency in permitting large charges to bo used, would, from the entire transference of the usual strain on pivots, racers, and carriages, to the immovable parapet or ship's side, effect a considerable saring in the construction of all that pertains to platforms, as well as a general saving in wear and tear from the absence of all jar and friction. It is further thought that it would effect a saving in the manufacture and alteration of orkhance, for it would diminish the amount of metal hitherto considered necessary to be given to each piece in order to assist in resisting recoil.

A convenient length being agreed upon for the recoil of the gun, what diameter should be given to the piston starting from a state of rest in air of a known density, could be computed in the following mamer:-

Let-

$a=$ area of cylinder in square inches.

$p=$ pressure per square inch on piston at commencement of stroke.

$s=$ length of cylinder in fect. Much detcrmined by the pressure it can innocuously sustain.*

$l=$ length of stroke of piston in feet. The length the gun recoils.

Then,

$\frac{s}{s-l} a p=$ pressure on piston at termination of first length of stroke, and thercfore the greatest pressure.

$\therefore$ a p $\sqrt{\frac{s}{s-l}}=$ mean pressuro during stroke.

$\therefore a p \sqrt{\frac{s}{s-l} l} l=$ total units of work done in first length of stroke in bringing the gun to a stand-still.

* That pressure per square inch on cylinder will cqual $2 p$ if $l=\frac{s}{2}$

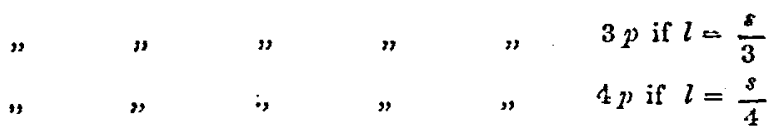

and so on. 
Again, weight of gun with its carriage, and of the shot and its initial relocity being known,

If $\mathrm{IV}=$ weight of gun and carriage in lbs.

$\mathrm{w}=$ weight of shot in $\mathrm{lbs}$.

$\mathrm{V}=$ initial velocity of recoil.

$\mathrm{v}=$ initial velocity of shot.

Then by the Artillery rule,

$\frac{V}{v}=\frac{\mathrm{w}}{\mathrm{W}} \therefore \mathrm{V}=\frac{\mathrm{w}}{\mathrm{W}} \mathrm{r}$.

$\therefore$ The total number of units of work accumulated in gun and

carriage duriug recoil $=\frac{\mathrm{W}}{2 \mathrm{~g}}\left(\frac{\mathrm{w}}{\mathrm{WV}} \mathrm{v}\right)^{2}=\frac{\mathrm{w}^{2} \mathrm{v}^{2}}{2 \mathrm{gWV}}$

But this accumulated Fork is overcome by the work done by the cylinder in bringing the gun to rest.

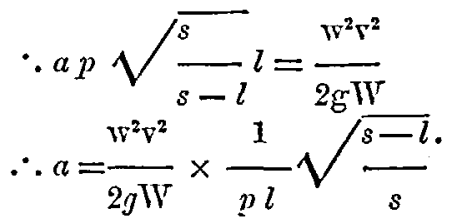

From this equation the area of the piston becomes known, hence its dinmeter.

The Crimares: If any gentleman has any remarhs to offer we shall be glad to hear them. It is a rery interesting subject, new to most of us, I daresay; as for myself there are one or tro points that I should like to ask a question about, if Captain Scott is in a position to clear them up. First of all, when the mortar (Fig. 8) Ins recoiled to the position in which we see it, I do not see how it is to be loaded. Next, there seems to mo to be a weak point in connection with the wear and tear of the rope round the pirots. The next is a point that I should think would be only determined by actual trial, riz., that in the case of the compression of the air, heat would be eliminated on one side, the compressed air, and cold on tho other side, the rarefied air. These are points I think that can only be settled by actual trial. TWe know that the compression of air, rery strongly and very suddenly cffected, rould liberate a great deal of caloric on one side. The other point that struck me at the time it was mentioned, is the escape of air round the piaton. I fancy that rould require trial to prove whether it would be so or not. Those appear to me to be the weak points in that system. If any gentleman, who has thouglnt on the subject, would be kind enough to gire us his opinions, we slould be happy to hear them.

Captain Brckle, R.N.: May I ask what there is to prevent the liead of the cylinder coming out by the effect of the recoil ? How is that controlled?

Captain MoscrierF : I should like to ask whether the recoil would be in the airection of the piston, or if it would be Iateral ?'

Captain Scort: As to heat and cold, or changes of temperature, I do not think :.: t practically they would be found to excrcise any material effect; I do not think

is: $J_{i}$ would be found to be difficulties. The wearing of the rope is a rery great diffi$t y$, there can be no doubt of it; there is always a tendency to break at a nip.

* xerer, a rope may bo made of almost any strength, and with the turret

- 15, tackles and chains have been found to resist recoil ; jou have only to make

- $n$ large enough súd heary enough, and then you can get them to stand; it

- nainly a question of weight. A wire rope would hare etood but for the nip YOL. XIII. 
as: the roller, which is certainly awhward. Therefore, you could only use a (j-n, and a chain of a particular character, riz., a pitch chain coiling orer a cirm, and I hare no doubt that in that way you would get orer the diffeulty. As to I anding, I take this to be rather a fancy sketch than the position in which a we tar would ever be placed. Of course it rould not turn up in that way, for it Ficld come down gradually in this line, and then you could load; but in the other unless you had a platform across you could not lond. As to the head of thre cylinder going, on the piston being pulled formard, the air acts as a cushion, compressed in the way it is shown, and the air being a cushion would nerer allow the piaton to come close against the head of the cylinder, and stribe it, there would al ways be an amount of compressed air which would act as a cushion to prerent any damage to the head of the cylinder. I do not think there would be any prictical difficulty. With regard to another question, the recoil would be in the diraction of the piston, which, in this case, would correspond exactly with the waterbeffer piston.

Captain MIoxcriefF : Would that be the case with the mortar?

Captain Scorr: Yes, certainly it would, becauso if it wero laid in the way shom, it would keep as indieated, you conld not alter the line, it must really more in it. Iou hare only to get the axis of the cylinder parallel with the line in which the piston is moring; there would be no practical difficulty in that, and then the packing Fould keep it steady. I confess it is a subject in which we hare not many experiment $s$ to guide us, and the limits between success and failure are extremely narrow. I do not think the plan should be set aside without rery careful experiment. I am sorry that General Hutchinson is not here, because lie has gone thoroughly into the matter, and could explain it far better than I can. But granting that it succeded, it would hare a very great adrantage orer water, which is now being tried. Water, as we all know, is incompressible, and when water is sct in motion by the recoil, the great check is at the first instant, and it becomes gradually less. Now, that is a wrong principle; you want the gun to recoil at first as ensily as jou can, and then to be brought up more and more gradually. If the air mould do that, jou would hare a perfect compressor; therefore, if it can be suceessfully worked out, it be good plan.

Captain Moxcrifrs : I should not Iare made auy remarks, only General Hutehinon thas employed as an illustration a form of carriage wilch I hare introduced, aud $I$ think I ought to say $a$ fow words about his rery interesting programme. The quetion of abzorption of recoil and of utilising the recoil of guns is a problem which he istracted the minds of sereral mechanical men lately; it is one which possesses very great fascination. There is no doubt whaterer that the idea of using an elastic medium so perfect as air to absorb, that recoil, is a very pretty one. I may state to this mecting that four years ago.I myself made designe for applying it to the carriaro which bears my name. From the drawings, which of course are mere sketches, I am afraid Gencral Hutchinson has not arrived at that stage in the process in which the real difficulties are discorered. Tho mere idon of applying air is a good one, but there are dificulties lying betreen the idea and the application of it. 1 moticed in the remarks which Captain Scott mede that he took credit not only for the adrantages of the compresecd air upon one side, but for the adrantages on the other side, which would hare been derired from the weight of the atmosphere. Of course, if you use the one, you cannot use the other to the same extent as when the reuum exists. I would prefer not to criticise the use of rop passing orer pulleys, and the other arrangements which I sce depicted there; they evidently repreaent the investigation at an early stage. I think the subject is one in which there is a great doal to be done, and I hope mjsclf to be able to describe at this Institution, some athar methods of applying the same power. With rogard to the mortar; it occurs to - that an clastic medium of a more solid character would be better suited for the Frose, and would make the traversing arrangements less un wieldy than those which - there depicted.

-ptain Scotr : If you would allow me to add one more remark, I would say that Creral Hutchinson only intended to put formard designs, not flnished models; he - merely shown the way in which his system can be applied. And after all, if it 
can be applied in these ways, jou hare really the back-bone of the sjstem. Al. though there are great difliculties to be met, as we all hnow well hicre are with erery inrention, because the linit between success and failure is so exceedingly narrow, still I think they may be fairly taken $\mathrm{s}$ well worth rery full consideration. With respect to the trafersing armangement, General IIutchinson, I suppose, merely put that in, not thinking that he would be treading upon any person's toes. I think there is nothing more than that in it, for many arrangements can be made to traverse the gun without a rack and pinion, which is perhaps the simplest plan. I think, howerer, that the discussion of this subject should be directed rather as to whether air cannot be usefully employed, than to any particular details, and this seems to bo the object that General IItutehinson has in view.

Major-General Borle1c, F.R.S. : I should wish to saj a rord before the subject closes, merely to give a general opinion upon the project, because it is simply a project at present. The question of utilising recoil has for some time oceupied the attention of the authoritics, and that some method of this hind is desirable, it oceurs to me, is prored by the fact of the water-buffer, or the application of water for the samo purpose as this, which is now being experimented upon at Shocburgness. Captain Scott has rery clearly pointed out that the great objection to water is, that it checks the recoil too suddenly at first, and that the action of water then becomes gradually diminished, until at the time when it is most wanted it ceases to act altogether. I think the introduction of air in a perfectly air-tight eylinder, such as I suppose these are to be, and which is not a matter of dificulty in practice, is, as a first idea, worthy of all consideration by the authorities. If water has been applied successfully to check the rccoil of guns, it is iny opinion that air may be applied more successfully to tho same purpose, because it better fulfils the conditions which are required than water does. Without entcring into the detail of the principles, and of the proportions neceenry for that air cylinder to meet the recoil of large gunz, I think the design is one wlich crhibits great ingenuity, and which, if it can be successfully applied, will be likely to produce great and useful practical results. And should such results oceur, it will only be one more added to the many instances of useful national imrentions, tending to place our country in its present adranced position in regard to artillery, which have been brought formard in this Institution.

The Cintrurax: I am sure we all feel rery much obliged to General IIutchinson; Wha unaroidable absence we regret, for haring giren us this paper. I must coneur in $\therefore-:$ - narks that General Boileau has made, indeed in all the remarks that hare fallen i: - entlemen; they gire a good summary of the subject. It is but fair to say of t: a : an, that thougl I and others might criticise the ropes and other details, wo $\therefore 1 .$. remember that the illustrations are simply sketehes and nothing more, intended tu c: : rey an idea, which idea would be worked out practically to a good and sound conasion as soon as we know the forces we hare to deal with better than we do now. For instance, I would not take that rough sketch as a representation of what th.: invention is likely to come to hereafter, any more than I would take that shetch of a luman figure as a representatire and model of the beanty of a sailor. Still it sirres to conrey to our eyes the idea of a sailor. So this sketch gires us an idea of what the inrention may be hereafter. The idea is the thing re hare to deal with now, the proctical working out is to be done by-and-bye. There are difliculties no donbt to be cncountered, but I beliere those difliculties will be got orer by the talent of mechanicians in this country. Te are rery much obliged to General Hutehinson for his paper, and we are equally obliged to Captain Scott for the ray in which he has resd it. I hare now the pleasure to introdnce to you Mrr. Stone, of the 77th Regiment, who will cxhibit models illustrative of his new gun platfomo. 